\title{
CASE REPORT: LIFESAVING THERAPEUTIC PLASMA EXCHANGE BY CELL SAVER IN AN OBSTETRIC EMERGENCY
}

\author{
Marija Vranes ${ }^{1}$, Zvezdana Lojpur'1, Milena Todorovic'², Gordana Ostojic ${ }^{3}$, Elizabeta Ristanovic ${ }^{3}$, Bela Balint ${ }^{3,4}$ \\ ${ }^{1}$ Department for Transfusion Medicine, Clinical Center of Kragujevac, Kragujevac, Serbia \\ ${ }^{2}$ Clinic for Hematology, Clinical Center of Serbia, Belgrade, Serbia \\ 3 Military Medical Academy, Belgrade, Serbia \\ ${ }^{4}$ Serbian Academy of Sciences and Arts, Belgrade, Serbia
}

\section{PRIKAZ SLUČAJA: TERAPIJSKA ZAMENA PLAZME PUTEM AUTOLOGNE TRANSFUZIJE U AKUŠERSKOM URGENTNOM STANJU}

\author{
Marija Vranešl, Zvezdana Lojpur ${ }^{1}$, Milena Todorović ${ }^{2}$, Gordana Ostojić ${ }^{3}$, Elizabeta Ristanović ${ }^{3}$, Bela Balint 3,4 \\ ISlužba za transfuziju, Klinički centar Kragujevac, Kragujevac \\ ${ }^{2}$ Klinika za hematologiju, Klinički centar Srbije, Beograd \\ ${ }^{3}$ Vojnomedicinska akademija, Beograd \\ ${ }^{4}$ Srpska akademija nauka i umetnosti, Beograd
}

\section{ABSTRACT}

Introduction. Abnormally high levels of triglycerides (hyperlipidemia) are often the result of a number of disorders in the body, which over time can lead to conditions such as hypothyroidism, nephrotic syndrome, diabetes, obstruction of the biliary ducts, hepatic impairment et al. The topic of how to treat the extreme hyperlipidemia has been an important discussion point in medical circles.

Case report. This paper presents the case of a 33-yearold pregnant women in the 34th week of the first proper pregnancy with laboratory-verified extreme hyperlipidemia, who was brought in critical condition to the Clinical Center of Kragujevac. After the emergency cesarean section was performed, due to the general poor condition of the patient and extremely high levels of triglycerides and cholesterol, lipopheresis was indicated, which in our institution was not technically possible to treat and therefore it was necessary to find an alternative solution.

Conclusion. It was shown that the application of intraoperative blood salvage can be used successfully not only in heavy bleeding during surgery, but also for cleaning the blood itself, which was clearly shown in the laboratory analysis.

Key words: hyperlipidemia, operative blood salvage, blood transfusion, autologous.

\section{INTRODUCTION}

Hyperlipidemia (HL) is defined as abnormally elevated levels of any or all lipids and/or lipoproteins in the blood, and it is classified according to the type of elevated lipids as hypercholesterolemia, hypertriglyceridemia or both (combined HL). The lowdensity lipoprotein plasma level is enlarged, as well. HL is usually asymptomatic - but it may be associated with hemorheological abnormalities and hypercoagulability, vascular/atherosclerotic events and other comorbidities,

\section{SAŽETAK}

Uvod. Povećane vrednosti triglicerida (hiperlipidemija) obično su posledica niza poremećaja u organizmu koji vremenom mogu dovesti do stanja poput hipotireoze, nefrotskog sindroma, dijabetesa, opstrukcije žučnih puteva, oštećenja funkcije jetre $i$ dr. Kako lečiti ekstremnu hiperlipidemiju značajna je tema za diskusiju u medicinskim krugovima.

Prikaz slučaja. U ovom radu prikazan je slučaj 33godišnje trudnice u 34. nedelji prve uredne trudnoće sa laboratorijski verifikovanom ekstremnom hiperlipidemijom, koja je u kritičnom stanju dovezena u Klinički centar Kragujevac. Nakon hitno izvršenog porođaja carskim rezom zbog opšteg lošeg stanja pacijentkinje i ekstremno visokih vrednosti triglicerida i holesterola, indikovana je lipofereza, za čiji tretman u našoj ustanovi ne postoje tehničke mogućnosti, te je bilo neophodno pronaći alternativno rešenje.

Zaključak. Pokazano je da aparat za intraoperativno spasavanje krvi može biti uspešno upotrebljen ne samo kod obilnog krvarenja u toku hirurške intervencije nego $i$ za čišćenje same krvi, što jasno pokazuju laboratorijske analize.

Ključne reči: hiperlipidemija, operativno spašavanje krvi, transfuzija krvi, autologna.

such as pulmonary embolism. Treatment of HL includes anticoagulant and lipid-reducing medication, seldom combined with plasma exchange (TPE). TPE reduces patient's load with excessive total cholesterol (TChl) and serum triglyceride (STG) to the level that will allow improvement $(1,2)$. Typically, STG reduction $\geq 50 \%$ could be associated with positive effects $(2,3)$. The aim of this article is to present an "unconventional" ("personalized") TPE for rapid STG/TChol-depletion in an obstetric emergency with extreme TChl/STG. 


\section{CASE PRESENTATION}

A 33-year old female, at 34th week of gestation with hypertrigliceridaemia, hyperlipoproteinemia type-IIB (HLP-type-IIB), diabetes mellitus type 2 and obesity, in state of ketoacidosis, has been sent to Clinical Center Serbia in critical general condition. In a previous medical history, the patient was treated for acute pancreatitis a few months before pregnancy, as part of hypertriglyceridemia and HLP-type IIB. By the third month of pregnancy she took the omega-3 acid ethyl esters, and colestipol (Colestid®).

Due to additional clinical worsening, she was "redirected" into the nearest medical institution (Kragujevac), and was admitted to our Clinical Center. Urgently, the Caesarian-section was done to save the female newborn. She delivered a healthy pre-term infant at 34th week of gestation (birthweight $2600 \mathrm{~g}$, Apgar score 9), without any maternal or fetal complications during gestation or delivery. Following this intervention, clinical status of the mother was life-threatening - including hemorheological/hemostatic disturbances, suspected pulmonary embolism with severe dyspnea (mechanical ventilation was required), chest pain, tachycardia (heartrate $=126 / \mathrm{min}$ ) and neurological dysfunctions (confusion).

The most important laboratory data were shown in Table 1 and Table 2.

Due to excessive HL, hemostatic screening tests were not applicable and the determination of coagulation factors was not possible.
During the hospitalization the patient received intravenous human fast acting insulin $(0.4 \mathrm{U} / \mathrm{kg} / \mathrm{h})$ and was titrated to a glucose level $<10 \mathrm{mmol} / \mathrm{L}$. Since heparin can initially lower STG-level (by stimulating the release of lipoprotein lipase) it was administered with titration for a target partial-thromboplastin-time $<100 \mathrm{~s}$, but without improvement in the patient's triglycerides.

Given that it was a life-threatening condition, it was decided to reduce the extreme TChl/STG levels. TPE was indicated - to reduce the patient's excessive STG/TChol levels and to prevent the HL-related complications - but it was technically not possible, due to the lack of cell separator device in our Clinical center. Consequently, an unconventional-TPE by Cell Saver (Haemonetics, USA; using a technique different from the manufacturer's directions) was performed (Figure 1a-1b). Vascular access was obtained across external jugular venous catheter. A sterile-connected plastic-bag-system was used as an alternative "whole-blood-source" for cell saver equipment. Washed/filtered RBCs (1200 mL) were directly returned into the patient's circulation. The removed plasma ( $2200 \mathrm{~mL}$; Figure 1c) with $20 \%$ albumin in saline was replaced. TPE-treatment was well tolerated by the patient, without adverse events. The patient was treated in accordance with good clinical practice and she was eligible for the use of "modified-apheresis-protocols" as certified by the Ethical Committee of MMA. Following this TPE, an "intensive-care-system" was applied.

Although the policy of "good-clinical/apheresispractice" was not followed and this approach cannot be recommended as a "standard-TPE-model" - the

Table 1. Results of laboratory parameters

\begin{tabular}{|l|c|c|}
\hline Parameter & Results & Reference range (unit) \\
\hline white blood cells (WBCs) & $18.8 \times 10^{9} / \mathrm{L}$ & $3.8-10.0 \times 10^{9} / \mathrm{L}$ \\
\hline red blood cells (RBCs) & $3.6 \times 10^{12} / \mathrm{L}$ & $3.86-5.08 \times 10^{12} / \mathrm{L}$ \\
\hline hemoglobin (Hb) & $122 \mathrm{~g} / \mathrm{L}$ & $110-160.4 \mathrm{~g} / \mathrm{L}$ \\
\hline platelets & $240 \times 10^{9} / \mathrm{L}$ & $150-400 \times 10^{9} / \mathrm{L}$ \\
\hline
\end{tabular}

Table 2. Results of laboratory parameters

\begin{tabular}{|l|c|c|}
\hline Parameter & Results & Reference range (unit) \\
\hline fibrinogen & $9.5 \mathrm{~g} / \mathrm{L}$ & $2.0-4.0 \mathrm{~g} / \mathrm{L}$ \\
\hline glucose & $23.3 \mathrm{mmol} / \mathrm{L}$ & $3.5-6.1 \mathrm{mmol} / \mathrm{L}$ \\
\hline total cholesterol (TChl) & $53.8 \mathrm{mmol} / \mathrm{L}$ & $<5.2 \mathrm{mmol} / \mathrm{L}$ \\
\hline Serumtriglyceride(STG) & $138.2 \mathrm{mmol} / \mathrm{L}$ & $<1.7 \mathrm{mmol} / \mathrm{L}$ \\
\hline
\end{tabular}




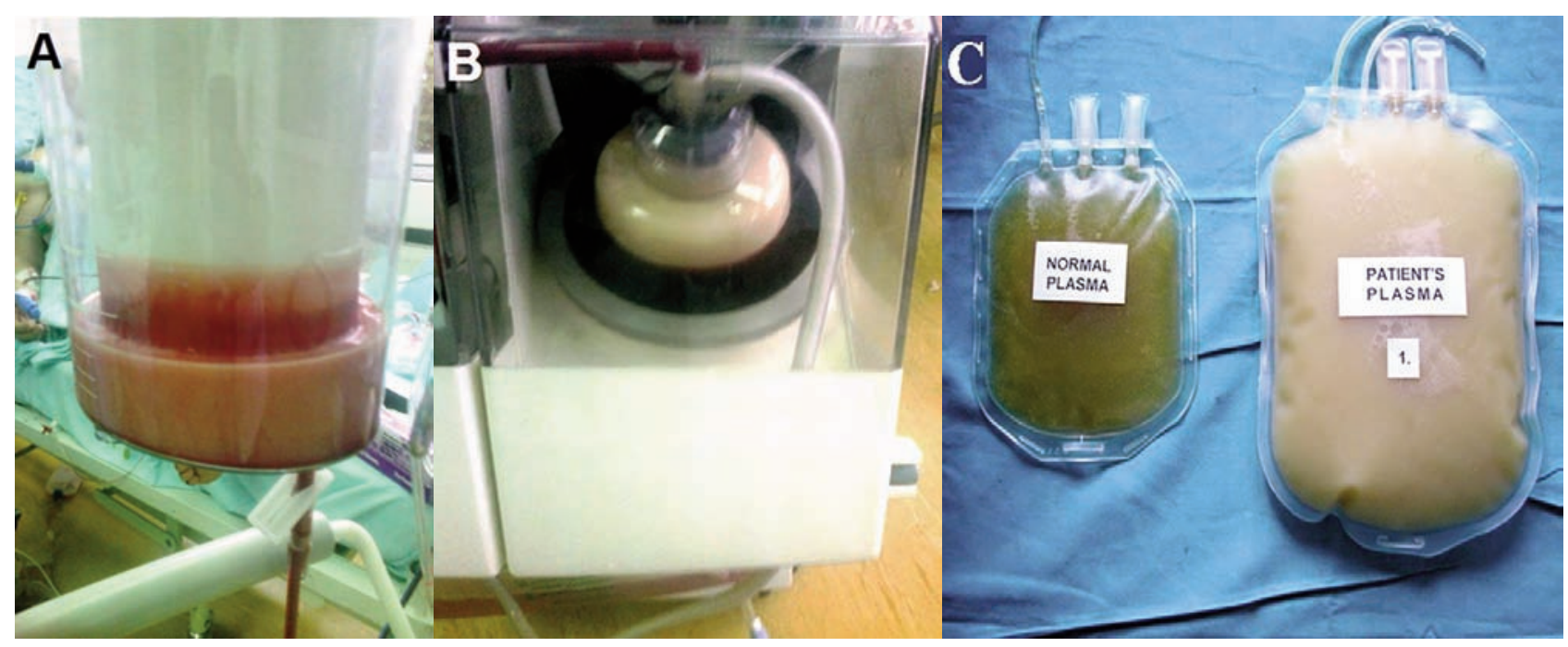

Figure 1. The TChl/STG-reductive TPE-treatment using Cell Saver:

A) The TPE-procedure starting point,

B) Presence of plasma with excessive TChl/STG in the device "bowl"

C) Comparison of the patient's removed versus normal plasma.

undoubtedly positive effects of this treatment, resulted in rapid hemorheological/hemostatic recovery, as well as correlation between the laboratory parameters $(\mathrm{TChl}=$ $14.6 \mathrm{mmol} / \mathrm{L}, \mathrm{STG}=24.9 \mathrm{mmol} / \mathrm{L}$ ) and the clinical results were observed. Patient had no further "hyperlipidemiaassociated-emergency" over three-month follow-up period. Further therapy with fibrates was performed in order to avoid recurrence of hypertriglyceridemia. This TPE was not associated with essential disease long-term remission, but the patient has been under chronic therapy, in good general condition, with her three-year old daughter nowadays.

\section{DISCUSSION}

Despite the fact that the pregnancy is usually associated with the mildly elevated levels of serum lipids (4) as well as that our pregnant patient was previously diagnosed with the diabetes mellitus type 2 and HLP-typeIIB, in this paper we present the case of very severe hypercholesterolemia and hypertriglyceridemia which were found in the same patient and successfully treated by unconventional-TPE. To our knowledge, this is the first report of using Cell Saver 5 (Haemonetics, USA - an autologous blood recovery system which is designed for use in transufusiology during the procedures where medium-to high-volume blood loss occurs) for the rapid/effective plasma lipid depletion in emergency care of the eight-month-pregnant women, aimed at reducing the risk of severe cardiovascular complications and/or acute pancreatitis.

There were numerous previous reports of the effectiveness of different "lypo-apheresis" manners in various patients suffering from severe hyperlipidemia (411). The most commonly used are different methods of lipoprotein apheresis and conventional plasmapheresis, especialy in patients with familiar or combined hiperlipidemia followed by very high levels of TChl and/or STG, where pharmacotherapy is contraindicated or inneffective (4-11). However, such extremely high levels of both TChl and STG registered in our pregnant patient were not reported previously, to our knowledge $(5,9,10)$. Additionally, "lypo-apheresis" as the safe and effective procedure, could be very helpful, especially in the pregnancy, not only to reduce the serum levels of TChl and/or STG, but also to decrease the risk of cardiovascular complications in future mothers $(9,10)$ as well as, on the other hand, to reduce the incidence of systemic inflammatory response syndrome (SIRS) and multiple organ dysfunction syndrome (MODS) in pregnant women with acute pancreatitis (5), possibly leading in both cases to the delivery of healthy infants.

Finally, this case report is particularly important in terms of pointing out on the significance of an urgent and intensive non-pharmacological therapy performed in the "state of last resort", using medical devicesthat having worked with method which was not in line with the instructions of the manufacturer, for reducing the high risk of abovementioned complications caused by extremely high levels of TChl and STG and co-existing pathological conditions.

In conclusion, this paper showed that the application of intraoperative blood salvage could be used successfully not only in heavy bleeding during surgery, but also for cleaning the blood itself, which was clearly shown by the laboratory analysis. After the treatment rapid laboratory 
effect was confirmed, with undoubtedly "cross - bridged" hemorheologic/hemostatic crisis. Our patient had no immediate hyperlipidemia-associated emergency and the treatment was not associated with long-term basic disease remission. Her pregnancy completed, giving the birth to a healthy baby girl. Rising number of well-documented cases, such as ours, may be useful to make optimal therapeutic decisions during medical emergencies in the future.

\section{CONFLICT OF INTEREST}

The authors of this paper have no conflicts of interest, including specific financial interests, relationships, and/or affiliations relevant to the subject matter or materials included.

\section{REFERENCES}

1. Saravanan P1, Blumenthal S, Anderson C, Stein R, Berkelhammer C. Plasma exchange for dramatic gestational hyperlipidemic pancreatitis. J Clin Gastroenterol 1996; 22: 295-8.

2. Balint B, Todorovic-Balint M, Petakov M, Ostojic G, Vucetic D. Effectively "cross-bridged" hemostatic and blood screening test defects due to glycogenosis type 1 associated extremely hyperlipidemia. Transfus Apher Sci 2014; 50: 314-5.

3. Bajpai M, Tyagi P, Maharshi S. Therapeutic plasma exchange in hyperlipidemic pancreatitis. Transfusion 2012; 52: 929.

4. Russi G. Severe dyslipidemia in pregnancy: The role of therapeutic apheresis. Transfus Apher Sci 2015; 53: 283-7.
5. Huang C, Liu J, Lu Y, Fan J, Wang X, Liu J, et al. Clinical features and treatment of hypertriglyceridemia-induced acute pancreatitis during pregnancy: A retrospective study. J Clin Apher 2016; 31: 571-8.

6. Stefanutti C, Labbadia G, Morozzi C. Severe hypertriglyceridemia-related acute pancreatitis. Ther Apher Dial 2013; 17: 130-7.

7. Stefanutti C, Julius U. Treatment of primary hypertriglyceridemia states--General approach and the role of extracorporeal methods. Atheroscler Suppl 2015; 18: 85-94.

8. Julius U. Lipoprotein apheresis in the management of severe hypercholesterolemia and of elevation of lipoprotein(a): current perspectives and patient selection. Medical Devices (Auckl.) 2016; 9: 349-60.

9. Ogura M, Makino H, Kamiya C, Yoshimatsu J, Soran $\mathrm{H}$, Eatough R, et al. Lipoprotein apheresis is essential for managing pregnancies in patients with homozygous familial hypercholesterolemia: Seven case series and discussion. Atherosclerosis 2016; 254: 179-83.

10. Blaha M, Lanska M, Blaha V, Boudys L, Zak P. Pregnancy in homozygous familial hypercholesterolemia-Importance of LDL-apheresis. Atheroscler Suppl 2015; 18: 134-9.

11. Diakoumakou O, Hatzigeorgiou G, Gontoras N, et al. Severe/Extreme Hypertriglyceridemia and LDL Apheretic Treatment: Review of the Literature, Original Findings. Cholesterol 2014; 109263. 